\title{
Incidence of type 1 diabetes mellitus in Passo Fundo, RS, Brazil
}

H.R.K. Lisbôa, R. Graebin, L. Butzke and C.S. Rodrigues
Departamento de Medicina Interna, Faculdade de Medicina, Universidade de Passo Fundo, Passo Fundo, RS, Brasil

\section{Correspondence \\ H. Lisbôa \\ Rua Teixeira Soares, 885/806 99010-901 Passo Fundo, RS Brasil \\ E-mail: hlisboa@pro.via-rs.com.br}

Research partially supported by $\mathrm{CNPq}$ and Universidade de Passo Fundo.

Received February 12, 1998 Accepted September 8, 1998

\section{Abstract}

To establish the incidence of type 1 diabetes among children (infants to 14 years of age) in the city of Passo Fundo, Rio Grande do Sul, Brazil (population under 15 years $=50,098$ ), during the period of January to December 1996, a retrospective and prospective population-based registry was established, using physician reports of newly diagnosed patients under 15 years of age with type 1 diabetes as the primary source of case identification. Primary and nursery schools and a general call through the media (newspapers, radio and television) was the secondary source. Data were calculated according to the methods recommended by the WHO (1990). Six new cases were identified. Case ascertainment was estimated at $100 \%$. The incidence of type 1 diabetes in the year 1996 was 12/100,000 inhabitants. These data indicate that the incidence of childhood type 1 diabetes in a subtropical region in the Southern part of Brazil was similar to that observed in developed countries throughout the world. The inability to demonstrate the North-South gradient is probably due to the European origin of inhabitants of the city.

The frequency of type 1 diabetes mellitus varies among countries and a "North-South gradient" with a reduced incidence in Southern Europe and other Southern parts of the world has been observed. However, there are exceptions such as Sardinia, located in the Southern part of Europe, which presents an incidence similar to that of Finland. Type 1 diabetes occurs more often in people of Northern European descent and is less prevalent among black Africans, Asians and native Americans (1-3).

No country below the equator presents a higher incidence than 20/100,000 inhabitants per year in contrast to 35.3 per 100,000 reported in Finland (3). No correlation be- tween incidence, latitude and mean annual temperature has been found. Differences within countries are rare but were observed in Nordic countries, the British Islands, Italy and the United States (4).

These differences in incidence may be explained by the increased prevalence of people carrying the susceptibility gene that allows the development of the disease. On the other hand, environmental factors have also been suggested to contribute to this difference (5). The prevalence of type 1 diabetes is increased among individuals who were not breast-fed or who received mother's milk only for a short period of time (6). Recently, Gimeno and Souza (7) showed 
that shorter duration of exclusive breastfeeding was a risk factor for type 1 diabetes and that the introduction to cow's milk before the age of 8 days was also a risk factor for the disease (7). Among the lines of evidence indicating that environmental factors play a role in the development of the disease is the continuous increase in the incidence over the last three decades $(8,9)$.

Data on the incidence of type 1 diabetes in South America are limited. Isolated studies conducted in São Paulo, Brazil (10), Chile (11) and Peru (12) have shown an incidence of 7.6, 2.5 and 0.4 per 100,000, respectively.

We studied the incidence of type 1 diabetes in Passo Fundo, State of Rio Grande do Sul, a city with 152,110 inhabitants in the highland region of Southern Brazil (latitude $28.10 \mathrm{~S}$, longitude $52.20 \mathrm{~W}$ ) during the year 1996. The estimated population of children under 15 years of age was 50,098. Since the study was started in July, the cases diagnosed during the first part of the year were collected retrospectively and those diagnosed thereafter were collected prospectively. The eligibility criteria were that the person had to be born in the city or to have been a resident for at least one year, be less than 15 years old, use insulin and have been diagnosed as a case of type 1 diabetes by a physician. The date of the first insulin injection was considered to be the beginning of the disease. To determine the degree of ascertainment and to estimate the true number of new cases, the Lincoln-Peterson technique of capture and recapture (13), modified according to Cochi et al. (14), was used. This technique, which was first used to prevent undercounting in the study of populations of wild animals, is based on capturing and tagging individuals by two or more independent sources. Among the target population, the first source (capture) identifies those individuals with the characteristic of interest. Other independent sources (recapture) examine the same population and search for new or al- ready identified individuals of interest. The following formula is then applied: $\mathrm{N}=\{(\mathrm{M}$ $+1)(\mathrm{n}+1) /(\mathrm{m}+1)\}-1$ where $\mathrm{N}=$ estimated number, $\mathrm{M}=$ number in the first sample, $\mathrm{n}=$ number in the second sample and $\mathrm{m}=$ number of individuals identified in both samples. With a high degree of ascertainment, the total number of individuals with the feature of interest, in our case patients with type 1 diabetes mellitus, can be obtained. The formula used to calculate variance is $\operatorname{Var}(\mathrm{N})=$ $(M+1)(n+1)(M-m)(n-m) /(m+1)^{2}(m+2)$ and the formula used to calculate the confidence interval is: $95 \% \mathrm{CI}=1.96 \sqrt{ } \operatorname{Var}(\mathrm{N})$.

The primary source (capture) consisted of all pediatricians $(\mathrm{N}=39)$ and all endocrinologists $(\mathrm{N}=5)$ who were contacted by means of three sequential letters and by monthly telephone calls requesting that they report cases of type 1 diabetes diagnosed during that year. These doctors were the most likely to have referred patients with type 1 diabetes. The secondary source (recapture) was information obtained from primary schools $(\mathrm{N}=34)$, from nursery schools $(\mathrm{N}=49)$ and from the local Diabetes Association. For recapture, a message was sent to the entire population in December through the newspapers, radio and television reaching 20,60 and $84 \%$ of the local population, respectively. The cases identified through the secondary sources were compared with those identified by physicians.

The population of Passo Fundo is $86 \%$ white, mainly of Portuguese, Italian and German origin, $1.4 \%$ black, $12.5 \%$ mulatto, and $0.1 \%$ Indian (15).

The primary source identified 6 patients and all 3 patients from the secondary source were common to both sources. Two patients were captured retrospectively and four prospectively. They were three boys aged 4,9 and 12 years (mean 8.3) and 3 girls aged 7, 9 and 10 years (mean 8.7). The variance and confidence intervals were not computed since all cases from the secondary source were included in the primary source. The esti- 
mated incidence was 12 cases/100,000/year. The degrees of ascertainment were $100 \%$ for the primary source, $50 \%$ for the secondary source and $100 \%$ for both sources (Table 1). The small number of cases did not permit us to reach conclusions about seasonal and sex frequency.

We estimate an incidence of 12 cases/ 100,000 /year with a high degree of ascertainment. We plan to include other secondary sources such as insulin sales records and hospital registries in the continuation of our research in order to improve the accuracy of our secondary source. Our results indicate an incidence higher than the 7.6 cases/ 100,000/year reported for São Paulo (10), a city in the Southeast (latitude $23.32 \mathrm{~S}$, longitude $46.37 \mathrm{~W}$ ) located $1000 \mathrm{~km}$ from Passo Fundo. It has been proposed that population variation in the prevalence of type 1 diabetes mellitus susceptibility genes is a primary determinant of the world-wide patterns of the disease (16). The early settlers of Passo Fundo were Brazilian-Portuguese individuals who arrived in the region in 1827 coming from São Paulo and bringing black slaves from Africa with them. German immigrants came 10 years later and Italian immigrants, most of them from Northern Italy, arrived around the beginning of the century (17).

We have no official data on the prevalence of European ethnic groups in the city, but an inspection of the telephone list of 1996 showed that Italian family names predominate $(45 \%)$, followed by Portuguese $(25 \%)$, German (18\%) and other ethnic groups (10\%).

A recent study showed that regions in Portugal and Spain present a prevalence of 8.5 and 10.9 cases/100,000/year, respectively. In Northern Italy, an incidence of 11.6 was reported for the Piemontese Province of Aosta and an incidence of 10.9 for the Province of Vicenza (Venitian region). None of the 8 regions studied in Italy presented an incidence of less than 6.5 cases/
Table 1 - Incidence of type 1 diabetes mellitus in Passo Fundo, RS, Brazil.

Number of cases in the 0-14 year age range from the primary and secondary sources, ascertainments and estimated incidence rate of type 1 diabetes are reported. The city had 50,098 persons under 15 years at the time of the study.

Primary source cases 6

Secondary source cases 3

Primary source ascertainment (\%) $\quad 100$

Secondary source ascertainment (\%) 50

Total estimated ascertainment (\%) $\quad 100$

Estimated incidence rate $(x 100,000) \quad 12$

100,000/year. In the Eastern part of Germany (former GDR) an incidence of 7.4 cases/100,000/year has been recently reported (4).

Analysis of these data showed that the incidence of type 1 diabetes mellitus in Passo Fundo is similar to that observed in Portugal, Spain, Northern Italy and Germany from where our ancestors came. This report, although limited by the size of the sample, indicates that the incidence of childhood type 1 diabetes mellitus in a subtropical region in the Southern part of Brazil is within the range observed in developed countries throughout the world and can be explained by the European origin of the population.

However, this study should be continued to cover a larger population sample.

\section{Acknowledgments}

We are indebted to Professors Dr. Marjatta Karvonen, National Public Health Institute, Helsinki, Finland, Dr. Laercio Franco, Departamento de Medicina Preventiva, Universidade Federal de São Paulo, São Paulo, SP, Brazil and Dr. Jorge Luiz Gross, Departamento de Medicina Interna, Universidade Federal do Rio Grande do Sul, Porto Alegre, RS, Brazil, for helpful assistance and suggestions. 


\section{References}

1. Rodger W (1991). Insulin-dependent (type I) diabetes mellitus. Canadian Medical Association J ournal, 145: 1227-1237.

2. Diabetes Epidemiology Research International Mortality Study Group (1991). Major cross-country differences in risk of dying for people with IDDM. Diabetes Care, 14: 49-54.

3. Green A, Gale EAM \& Patterson CC (1992). Incidence of childhood-onset insulin-dependent diabetes mellitus: The EURODIAB ACE study. Lancet, 339: 905909.

4. Karvonen M, Tuomilehto J, Libman I \& LaPorte R (1993). A review of the recent epidemiological data on the world-wide incidence of Type 1 (insulin-dependent) diabetes mellitus. Diabetologia, 36: 883892.

5. Maclaren N \& Atkinsons M (1992). Is insulin-dependent diabetes mellitus environmentally induced? New England J ournal of Medicine, 327: 348-349.

6. Kostraba J N (1994). What can epidemiology tell us about the role of infant diet in the etiology of IDDM? Diabetes Care, 17: 87-91.

7. Gimeno SGA \& Souza J MP (1977). IDDM and milk consumption. A case-control study in São Paulo, Brazil. Diabetes Care,
20: $1256-1260$.

8. Tuomilehto J, Rewers M, Reunanen A, Lounamaa R, Tuomilehto-Wolf $E$ \& Åkerblom HK (1991). Increasing trend in type 1 (insulin dependent) diabetes mellitus in childhood in Finland. Diabetologia, 34: 282-287.

9. Drykoningen $\mathrm{CE}$, Mulder AL, Vaandrager GJ , LaPorte RE \& Bruining GJ (1992). The incidence of type 1 (insulin-dependent) diabetes mellitus is rising rapidly in the Netherlands. Diabetologia, 35: 139-142.

10. Ferreira SR, Franco LJ, Vivolo MA, Negrato CA, Simões AC \& Ventureli CR (1993). Population-based incidence of IDDM in the State of São Paulo, Brazil. Diabetes Care, 16: 701-704.

11. Carrasco E, Lopez G, Garcia de los Rios M \& Vargas N (1992). Incidencia de diabetes mellitus insulinodependiente en menores de 15 anos. Período 90-91. Santiago, Chile. Revista de la Sociedad Argentina de Diabetes, 26 (Suppl): 14-15.

12. Seclen $S$, Rojas MI, Nuñez O, Valdivia $H$ \& Millones B (1997). Type 1 (Insulin-Dependent) Diabetes in Mestizo children of Lima, Peru. Report on a ten years (19851994) incidence. The Proceedings of the International Diabetes Epidemiology Group Symposium. Savonlina, Finland
(Poster No. 008).

13. Cormack RM (1968). The statistic of capture-recapture methods. Oceanography and Marine Biology: An Annual Review, 6: 455-506.

14. Cochi SL, Edmonds LE, Dyer K, Greaves WL, Marks J S, Rovira EZ, Preblub SR \& Orenstein WA (1989). Congenital rubella syndrome in the United States, 19701985. On the verge of elimination. American J ournal of Epidemiology, 129: 349361.

15. Censo Demográfico (1991). Resultados do universo relativo às características da população e dos domicílios. No. 24. Rio Grande do Sul. Censo Demográfico, Rio de J aneiro.

16. Dorman J S, LaPorte RE, Stone RA \& Trucco M (1990). World differences in the incidence of type 1 diabetes are associated with amino acid variation at position 57 of the HLA-DQ B-chain. Proceedings of the National Academy of Sciences, USA, 87: 7370-7374.

17. Xavier e Oliveira FA (1990). Annaes do Município de Passo Fundo. O Município de Passo Fundo Através do Tempo. Ed. Universidade de Passo Fundo, Passo Fundo, 2: 289-304. 